\title{
SULFUR ISOTOPES IN FINNISH NICKEL-COPPER OCCURRENCES
}

\author{
HEIKKI PAPUNEN and MARKKU MÄKELÄ
}

\begin{abstract}
PAPUNEN, H. and MÄKELÄ, M. 1980: Sulfur isotopes in Finnish nickel-copper occurrences. Bull. Geol. Soc. Finland 52, 55-66.

The sulfur isotope composition of the Hitura, Kotalahti and Kylmäkoski $\mathrm{Ni}-\mathrm{Cu}$ ores was analyzed. The results have been compared with earlier sulfur isotope analyses of the Vammala, Laukunkangas and Oravainen Ni-Cu occurrences. Altogether 183 analyses were performed. The magmatic origin of sulfides is supported by the isotope compositions that deviate only slightly from the meteoritic value. It is suggested that the initial sulfur isotope composition was homogeneous, ${ }^{34} \mathrm{~S}$ values being ca. +2.5 at Hitura, +2.0 at Kotalahti, close to zero at Kylmäkoski and at Laukunkangas, -1 at Vammala and +2.8 at Oravainen. The metamorphic redistribution of sulfides and the mixing of magmatic $\mathrm{Ni}-\mathrm{Cu}$ sulfides with wall-rock iron sulfides cause local variations in $\delta^{34} \mathrm{~S}$ values.
\end{abstract}

H. Papunen: Institute of Geology and Mineralogy, University of Turku, SF-20500 Turku 50, Finland.

M. Mäkelä: Outokumpu Oy, Exploration, Box 27, SF-02201 Espoo 20, Finland.

\section{Introduction}

A number of Svecokarelian mafic and ultramafic bodies in southern and central Finland bear considerable amounts of $\mathrm{Ni}-\mathrm{Cu}$ sulfides; several of them have also been exploited as $\mathrm{Ni}-\mathrm{Cu}$ ores. The bodies abound in a ring-shaped area surrounding the central Finland granitoid area (Papunen et al., 1979, Häkli et al., 1979). The lithological environments of the intrusives are commonly metasedimentary rocks with compositional and structural characteristics of metaturbidites. Thus a geosynclinal origin is indicated for the sequence. Amphibolites displaying primary volcanic structures occur locally as interbeds of mica-gneisses. A common feature, observed as electromagnetic anomalies in the environment of the sulfide-bearing ultramafics, are the graphite- and sulfide-graphite schists. A high degree of metamorphism and migmatization of the wall rocks are typical of the area of sulfide-bearing ultramafics (Tontti et al., 1979). The ultramafics are also metamorphosed (Papunen, 1977; Papunen et al., 1979), and the present occurrence of sulfides is mainly controlled by metamorphic features. Papunen et al. (1979) pointed out that the geochemistry of ultramafic bodies indicates local assimilation of the components of the wall rocks. Besides numerous metamorphic features, both structural and textural, the sulfides also display textures considered to be orthomagmatic in origin. This is especially 
true for the most mafic members of the rock sequence (Häkli et al., 1979; Papunen, 1970).

The sulfides in the ultramafics may have derived from the same mantle source as the host ultramafic, or they may have been assimilated from the wall rocks by magma. The mechanism of sulfurization in the formation of $\mathrm{Ni}-\mathrm{Cu}$ sulfides has been widely discussed since the 1960s (e.g. Häkli, 1963 and 1971; Naldrett, 1966). The discussion has recently turned to the origin of the massive $\mathrm{Ni}$ sulfide deposits associated with ultramafic extrusive rocks (e.g. Lusk, 1976; Seccombe et al. 1977). Groves et al. (1979) incline to the view that some, at least, of the nickel ores of Western Australia were formed when ultramafic magma was contaminated by sulfur from a crustal source. Sulfur isotope data and the $\mathrm{S} / \mathrm{Se}$ of nickel ores are consistent with such a hypothesis (Groves et al., 1979).

Sulfur isotopes serve as a tool for studying the origin of sulfides in mafic and ultramafic rocks. If the primary sulfides in the rocks were formed from uncontaminated magma from a deep-seated source, the isotope ratio, ${ }^{32} \mathrm{~S} /{ }^{34} \mathrm{~S}$, should be close to the meteoritic value, and the $\delta^{34} \mathrm{~S}$ value should differ little from zero (e.g. Stanton, 1972). Deviating values have been attributed to postintrusional metamorphic changes or to contamination during intrusion by wallrock sedimentary or volcanic sulfides. For example, the sulfides of the Water Hen intrusion in the Duluth complex originate from assimilated sedimentary sulfides of the Virginia formation (Mainwaring and Naldrett, 1977); the similarity in isotopic composition between the sulfides in a marginal portion of the Bushweld complex and those in the footwall (Liebenberg, 1970) suggests contamination.

The high isotopic values in the Noril'sk sulfides were attributed to assimilation of anhydrite from the underlying sedimentary rocks (Godlevskii and Grinenko, 1963). In the Råna igneous complex, Norway, the graphiterich parts of sulfide-bearing mafic rocks display $\delta^{34} \mathrm{~S}$ values almost similar to the sulfide-rich metasedimentary black schists outside the intrusion. In contrast, the majority of the massive or disseminated sulfides in ultramafics or norites show $\delta^{34} \mathrm{~S}$ values indicating a magmatic origin (Boyd and Mathiesen, 1979).

The origin of the sulfides in the Ni-Cu deposits of southern and central Finland was studied by determining the sulfur isotope composition of the Hitura, Kotalahti and Kylmäkoski ores. In the following the results are compared with isotope data on some other Finnish deposits.

\section{The methods}

A pure sulfide fraction was carefully separated from the samples by handpicking under a binouclar microscope or by drilling under a microscope from polished sections. The sulfides from the Hitura serpentinite were too fine-grained for mechanical separation and they were extracted by a chemical method developed at the Exploration Department of Outokumpu Oy (P. Hautala, pers. comm., 1978). The isotope analyses were performed at the Laboratory of Economic Geology, Helsinki University of Technology, according to the methods described by Mäkelä and Tammenmaa (1977). The original data are available at the Institute of Geology and Mineralogy, University of Turku.

\section{The results}

Hitura

The geology and mineralogy of the Hitura $\mathrm{Ni}-\mathrm{Cu}$ deposit have been described by $\mathrm{Papu}-$ 
nen (1970) and by Häkli et al. (1976); some data were also included in the review by $\mathrm{Pa}-$ punen et al. (1979). The ore minerals are hosted by a serpentinite body that grades towards the contacts into amphibole-bearing peridotite and amphibole rocks. Sulfides abound in the peridotite and amphibole rocks at the outer margin of the body, and a weak, fine-grained sulfide dissemination occurs locally in the serpentinite core of the body (Fig. 1). Close to the western and eastern margins of the body the sulfides have accumulated in massive ore shoots that seem to be controlled by shears in the contact zone.

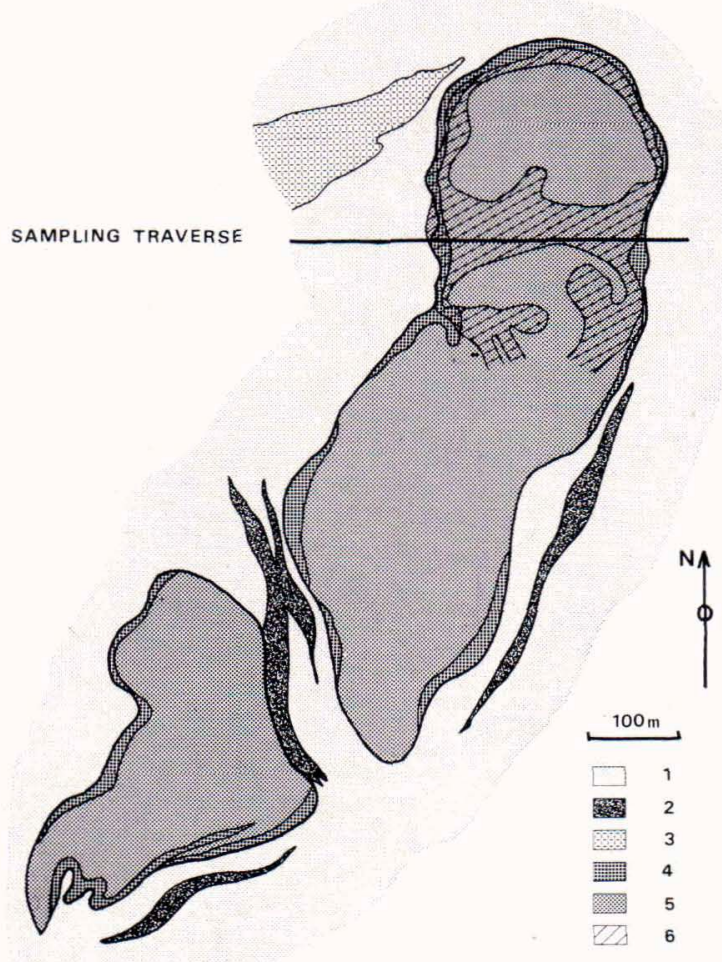

Fig. 1. Simplified map of the +205 level of the Hitura ultramafic body with the sampling traverse. 1. Mica gneiss, 2. graphite-rich gneiss, 3. quartz-diorite, 4. metaperidotite, 5. serpentinite, 6. $\mathrm{Ni}-\mathrm{Cu}$ ore.
The association pyrrhotite-pentlandite-chalcopyrite and occasional cubanite is common in the massive ore and heavy dissemination in peridotite and amphibole rocks, whereas the association pentlandite (and occasionally troilite) - mackinawite - valleriite abounds in the serpentinite. The textures indicate the secondary character of the latter mineral association, which evidently attained its composition during serpentinization. Also the migmatitic mica-gneiss wall rocks in the body contain a weak but persistent sulfide dissemination; these sulfides are, however, almost nickel-free except in the vicinity of the ultramafic body where the massive $\mathrm{Ni}-\mathrm{Cu}$ ore is in contact with the wall rock. Dispersion halos of $\mathrm{Ni}$ and $\mathrm{Cu}$ extending some ten meters from the massive ore are to be found in mica gneiss (Fig. 2).

The sulfur isotope composition was determined from 33 drill core samples taken from a traverse on the +205 level of the mine. Figs. 1 and 2 depict the location of the traverse, some of its geochemical characteristics and the results of the sulfur isotope analyses. In the $\mathrm{Ni}-\mathrm{Cu}$ ore close to the contact of the ultramafic body, the $\delta^{34} \mathrm{~S}$ values range from +0.9 to +3.5 per mil (Table 1 ); in the serpentinite core of the body they are more homogeneous, from +2.2 to +2.3 per mil. The sulfides of the gneissic wall rock show the $\delta^{34} \mathrm{~S}$ values from +3.2 to +6.0 per mil.

In the Hitura ultramafic body the average value of $\delta^{34} \mathrm{~S}$ is 2.4 per mil for sulfides of serpentinite and $\mathrm{Ni}-\mathrm{Cu}$ ore proper. This accords with the average $\delta^{34} \mathrm{~S}$ value of +2.4 per mil obtained by Ault and Kulp (1959) for sulfides in and associated with mafic igneous rocks. The sulfides in the gneissic wall rocks are isotopically heavier than those in the ultramafic body proper. One explanation is that the sulfides have a different origin. The zone where wall rock and magmatic sulfides mix shows up clearly as a nickel halo surround- 


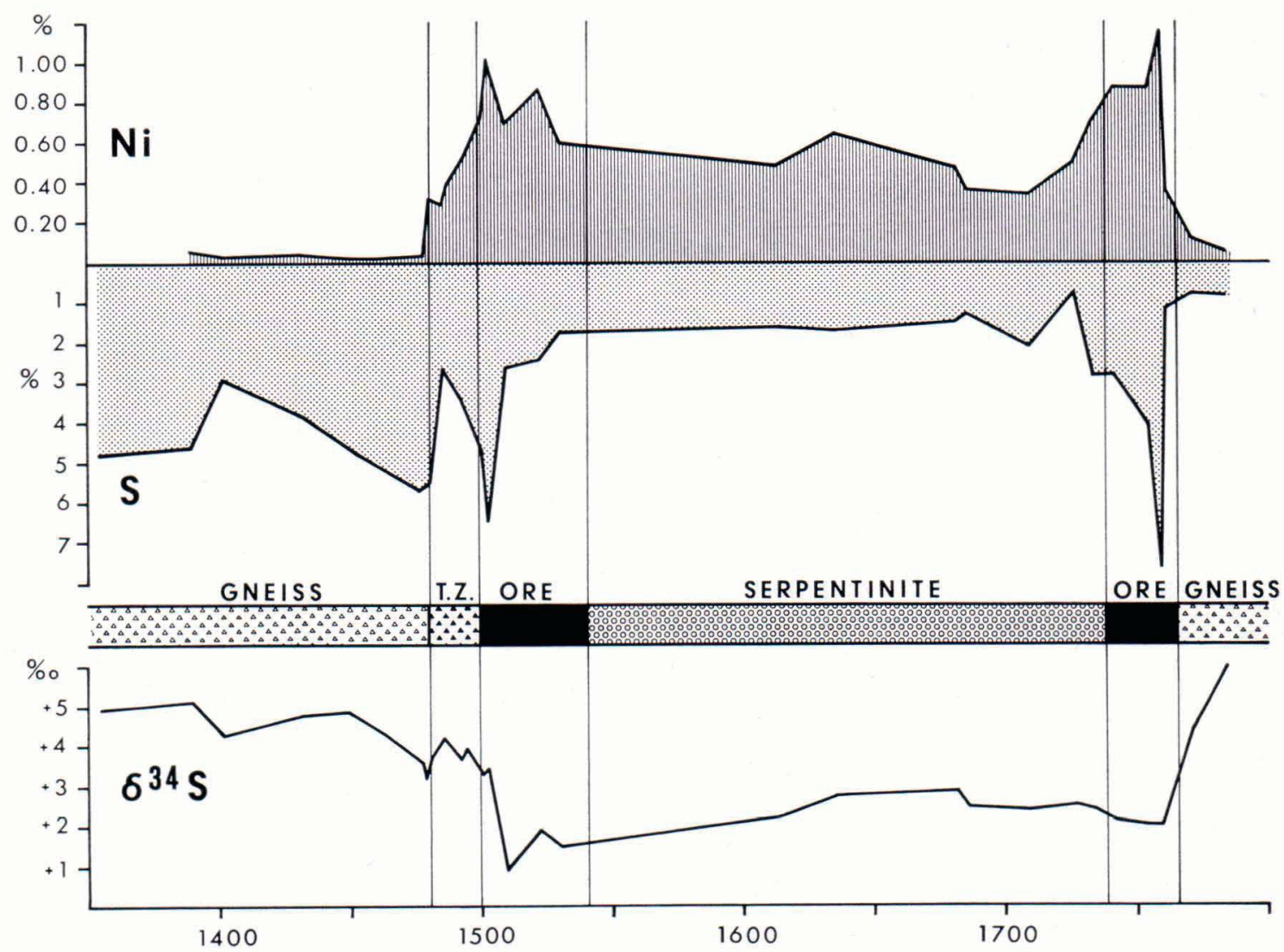

Fig. 2. Variation in the tenors of nickel and sulfur, rock type and $\delta^{34} \mathrm{~S}$ along the sampling traverse in Hitura (T.Z. = transition zone).

ing the contact of the ultramafic body. The relative amounts of nickel and copper in the halo and the gradual increase across the halo of the $\delta^{34} \mathrm{~S}$ value from $\mathrm{Ni}-\mathrm{Cu}$ ore to uncontaminated wall rock indicate that magmatic sulfides invaded the gneissic wall rock. The mixing of Ni-bearing and barren sulfides has further been observed by chemical analyses in the gneiss around the massive ore types in the Stormi ultramafite at Vammala (K. Vormisto, pers. comm., 1979).

The results indicate that the mobile compounds that formed the dispersion halos of $\mathrm{Ni}$ and $\mathrm{Cu}$ outside the ultramafic or mafic body proper were nickel copper sulfides, probably in the form of monosulfide solid solution that squeezed out of the ultramafic body.

Another feature of interest in the Hitura sulfur isotope data is that the sulfur in the disseminated and strongly altered sulfides is isotopically heavier in the serpentinite core than in the massive ore (Fig. 2). Papunen (1970) maintains that serpentinization has somewhat altered the original sulfide assemblages, and the present sulfide mineral association: pentalndite ( \pm troilite $)$ - mackinawite - valleriite ( \pm cubanite II) is the result 
of alteration. The original sulfur isotope composition was probably also affected by the same process. Owing to the higher water content, sulfur may oxidize into sulfate, and if the system is open for light sulfide, it may result in a slight enrichment in ${ }^{34} \mathrm{~S}$. On the other hand the sulfide content of the body increases towards the contacts (Fig. 2). Papunen (1970) explained this as a result of the diffusion of sulfur in response to temperature gradient during cooling and serpentinization in the primary intrusion. This is consistent with the theory expressed by Chamberlain (1967) for sulfide distribution in the Muskox intrusion. As ${ }^{32} \mathrm{~S}$ presumably diffuses faster than ${ }^{34} \mathrm{~S}$, the central serpentinite portion becomes depleted in ${ }^{32} \mathrm{~S}$. This also explains the more heterogeneous and reduced values of $\delta^{34} \mathrm{~S}$ in the $\mathrm{Ni}-\mathrm{Cu}$ ores close to the contact (Fig. 2); in addition to the original sulfides the peripheral areas also accumulated the diffused sulfides enriched in ${ }^{32} \mathrm{~S}$.

A fluctuating isotope pattern in many respects similar but generally much more complex has been noted by Sasaki (1968) in the contact zone of the Muskox intrusion.

\section{Kotalahti}

The Kotalahti ultramafic-mafic body is composed of peridotites, pyroxenites and their metamorphic derivatives, hornblendites, gabbros and diorites (Haapala, 1969; Papunen, 1970; Papunen and Koskinen, 1978). Papunen et al. (1979) came to the conclusion that the apparent differentiation series from peridotites to diorites is caused by intense assimilation of the wall rock neosome and that this in turn gives rise to the formation of the mafic and intermediate members of the series. The original intrusion could have been ultramafic in composition and intruded at an early stage of geosynclinal development at or close to an ancient granite gneiss basement of the sediments. This basement now crops out as a granite gneiss dome east of the plateshaped, vertical ultramafic body.

Sulfides abound in the ultramafic members of the series. Outside the ultramafic rocks proper, however, there is the massive Jussi ore body in the belt of calc-silicate rocks, cherty quartzites and amphibolites that Gáal (1972) considers to be a metamorphic derivative of the epicontinental sediments surrounding the granite gneiss dome. Pegmatite granites abound in the same belt.

The ore types of the ultramafic body are of the massive, brecciated and disseminated types (Papunen, 1970). The chemical composition of the sulfide phase varies according to the ore type. As trend is for the sulfur content in the sulfide phase to increase from the disseminated to the brecciated ore type and further to the massive type of the Jussi ore body. Likewise, the iron content in the sulfide phase is at a minimum in the Jussi ore body and at a maximum in the disseminated ore type of gabbro host rock. The disseminated ore type abounds in the most mafic members of the rock series, whereas the brecciated ores are controlled by tectonic features, shear zones, amphibolite dikes, pegmatites and contacts in the ultramafic body.

The sulfur isotope composition was analyzed from 36 samples (Table 1). The variation in $\delta^{34} \mathrm{~S}$ values is very limited ranging from +1.3 to +2.8 per mil, with an arithmetic mean of +2.1 per mil. In the main ultramafic body the $\delta^{34} \mathrm{~S}$ values are from 1.4 to 2.6 per mil. Isotopically there is little difference between disseminated and brecciated ore types in the ultramafic body. In the massive Jussi ore body the $\delta^{34} \mathrm{~S}$ values are usually slightly lighter than those in the ultramafic body proper (Table 1).

The mineral association: magnetite, pyrite, monoclinic pyrrhotite, chalcopyrite and pent- 
Table 1. Sulfur isotope data

\begin{tabular}{|c|c|c|c|}
\hline Locality & $\begin{array}{l}\text { Number of } \\
\text { samples }\end{array}$ & $\begin{array}{l}\text { Average } \delta^{34} \mathrm{~S} \\
\text { per mil }\end{array}$ & $\begin{array}{c}\text { Range of } \delta^{34} S \\
\text { per mil }\end{array}$ \\
\hline \multicolumn{4}{|l|}{ Hitura: } \\
\hline Serpentinite & 7 & +2.5 & $+2.2-+2.9$ \\
\hline $\mathrm{Ni}-\mathrm{Cu}$ ores & 9 & +2.2 & $+0.9-+3.5$ \\
\hline Wall-rock gneiss & 17 & +4.3 & $+3.2-+6.0$ \\
\hline \multicolumn{4}{|l|}{ Kotalahti: } \\
\hline $\mathrm{Ni}-\mathrm{Cu}$ ores & 29 & +2.1 & $+1.4-+2.6$ \\
\hline Jussi ore body & 7 & +1.8 & $+1.4-+2.8$ \\
\hline \multicolumn{4}{|l|}{ Kylmäkoski: } \\
\hline $\mathrm{Ni}-\mathrm{Cu}$ ore in ultramafic rock & 28 & -0.2 & $-1.6-+1.3$ \\
\hline $\mathrm{Ni}-\mathrm{Cu}$ ore in graphite-rich gabbro & 2 & & $-4.2--11.1$ \\
\hline \multicolumn{4}{|l|}{ Vammala (Häkli et al. 1979) } \\
\hline Upper ultramafic layer & 7 & +12.5 & $+5.4-+19.5$ \\
\hline Hornblendite layer & 13 & +1.5 & $-1.2-+2.6$ \\
\hline Lower ultramafic layer & 27 & -0.8 & $-2.2-+1.7$ \\
\hline \multicolumn{4}{|l|}{ Laukunkangas (Grundström, 1979) } \\
\hline Norite and gabbro & & & \\
\hline with $\mathrm{Ni-Cu}$ sulfides & & -0.2 & $\begin{array}{l}-4.3-+3.1 \\
-6.5--0.5\end{array}$ \\
\hline Graphite-schist & 25 & -2.6 & $\begin{array}{l}-6.5--0.5 \\
-6.5-+3.1\end{array}$ \\
\hline \multirow{2}{*}{\multicolumn{4}{|c|}{ Oravainen (Isohanni, 1979) }} \\
\hline & & & $+2.4-+3.4$ \\
\hline $\begin{array}{l}\text { Ni-Cu ore in peridotite } \\
\text { Graphite-schist }\end{array}$ & 2 & & $-7.8--8.1$ \\
\hline
\end{tabular}

The Laukunkangas data originally analysed by Mr. P. Hautala at the Laboratory of Geology and Geophysics, University of Utah, U.S.A.; all other data by M. Mäkelä at the Laboratory of Economic Geology, Helsinki Technical University.

landite, prevailing in the Jussi ore body, indicates that conditions during mineralization were more oxidating than in the ultramafic body, where pyrite and magnetite are rare. Oxidation of iron into magnetite resulted in the relative enrichment in sulfur, nickel and copper in the sulfide phase of the Jussi ore body (Papunen, 1974). The oxidation process was probably brought about by $\mathrm{H}_{2} \mathrm{O}$-rich wall rocks.

Thus a slight increase in the oxidation state of the ore-forming sulfides due to admixing with oxidized meteoric water may have resulted in a slightly lower $\delta^{34} \mathrm{~S}$ average in the Jussi ore body than in the sulfide phase of the ultramafics proper (Ohmoto, 1972).

\section{Kylmäkoski}

The Kylmäkoski ultramafic body is located in southwestern Finland in the belt favored by nickel-copper ores and called the PoriKylmäkoski zone (Papunen et al., 1979; Häkli et al., 1979). Kylmäkoski is about $40 \mathrm{~km}$ southeast of the major $\mathrm{Ni}-\mathrm{Cu}$ deposit of the belt, Vammala (Häkli et al., 1979).

The wall rocks in the $300-\mathrm{m}$-long ultramafic body are migmatized mica gneisses and a quartz diorite intrusive that intersects the body. The rock types are ultramafic: peridotites that are partly altered into metaperidotites, serpentinites or amphibole-rocks, and pyroxenites and hornblendites (Fig. 4). The 


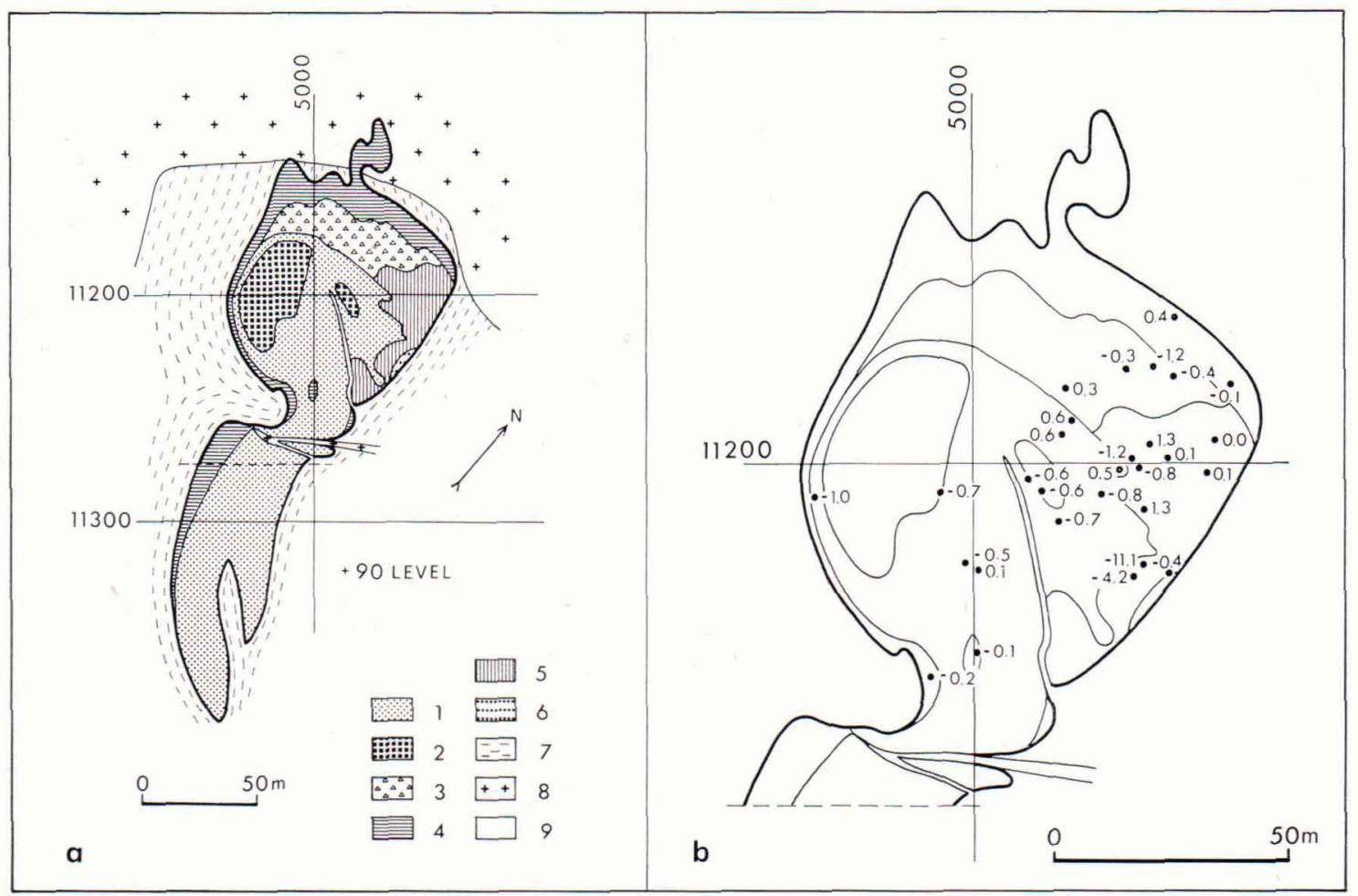

Fig. 4. (a) Geology and (b) sulfur isotope composition of the Kylmäkoski ultramafic body. 1. peridotite, 2. orbicular peridotite, 3. pyroxenite, 4. hornblendite, 5. cummingtonite-rock, 6. gabbro and diorite, 7. mica gneiss, 8 . quartz-diorite, 9. granite.

sulfides, which exist as disseminated, nettextured or brecciated ore types, are concentrated into lower parts of the body. Massive and disseminated nickel arsenides occur together with sulfides along the contacts of the quartz-diorite dikes.

Sulfur isotope composition was determined for 30 ore samples taken mainly from the $+90 \mathrm{~m}$ (surface) level of the mine. Despite the high sampling level, all of the samples were fresh, and no supergene alteration was observed in microscopic examination. The isotopic composition and location of the samples are depicted in Fig. 4. The $\delta^{34} \mathrm{~S}$ values range from -1.6 to +1.3 per mil with -0.2 per mil as a mean value of 28 samples. The frequency distribution diagram in Fig. 3 indicates that the isotopic composition of sul- fides varies somewhat more in Kylmäkoski than in Kotalahti and Hitura. No correlation was observed between isotope composition and ore type. Anomalously light sulfur was noted in two samples rich in graphite. The host rock of the graphite-bearing ore type varies from a biotite-hornblende gabbro to biotite diorite - the rock types that are met with only in this particular part of the ore body.

The primary differentiation series of the ultramafic body extends from orbicular peridotite to peridotite and further to pyroxenite. The hornblendite and perknitic varieties close to the contacts or at the tapering ends of the body were formed by wall rock assimilation. Thus, the graphite-bearing gabbro and diorite are the result of local wall-rock conta- 


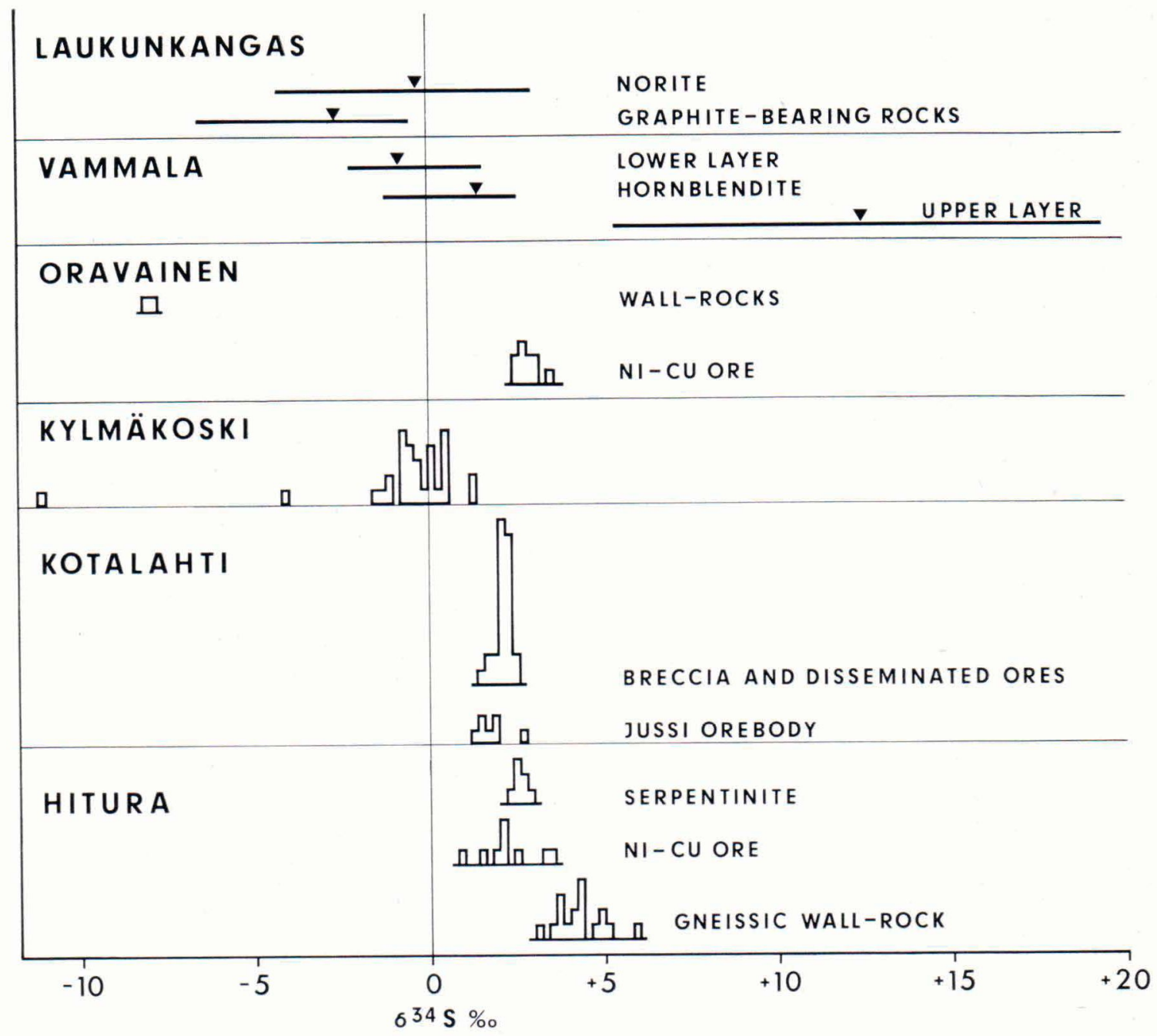

Fig. 3. Sulfur isotope distribution in the occurrences studied.

mination of the ultramafic melt. The alteration of pyroxenites into cummingtonite-tremolite rocks and of peridotites into serpentinites are the result of hydration during metamorphism. The sulfides have also undergone metamorphic redistribution, but no $\mathrm{Ni}$ $\mathrm{Cu}$ halo can be observed around the body. Only locally massive chalcopyrite-rich veins and breccias intersect the gneissous wall rock. The complicated metamorphic processes and contamination in this rather small ultramafic body have given rise to the wide range of $\delta^{34} \mathrm{~S}$ values.

Vammala, Laukunkangas and Oravainen

The data on the sulfur isotopes of Vammala and Laukunkangas in Fig. 3 and Table 1 were taken from studies by Häkli et al. (1979) and Grundström (1979). The unpublished data of Oravainen were kindly put at the author's disposal by M. Isohanni of Outokumpu Oy. 
V a m m a la

According to Häkli et al. (1979), the Vammala ultramafic body is composed of a pile of ultramafic layers resting one above the other. The lower and upper layers are composed mainly of peridotite, whereas the middle layer is hornblendite. The sulfide $\mathrm{Ni}-\mathrm{Cu}$ ore occurs in the lower peridotite layer; only a weak dissemination of sulfides exists in the hornblendite and upper peridotite layers. The textures of the sulfides in the upper layer indicate that the primary sparsely disseminated sulfides have altered into oxides due to oxidation, and that only remnants of the original sulfide grains remain.

The isotope composition of the main sulfide mass in the lower layer is rather homogeneous the $\delta^{34} \mathrm{~S}$ values ranging from -2.2 to +1.7 per mil (Table 1 ). In the hornblendite layer, the sulfur is slightly heavier, $\delta^{34} \mathrm{~S}$ averaging +1.5 per mil. The sulfur isotope composition of the sulfides in the upper metaperidotitic layer differs decisively from that in the lower layers, the $\delta^{34} \mathrm{~S}$ values varying between +5.4 and +19.5 per mil, the average being +12.5 per mil.

It is hardly possible that the sulfides with an average $\delta^{34} \mathrm{~S}$ of +12.5 per mil could be purely magmatic in origin. Häkli et al. (1979) concluded that the original sulfides in the upper layer oxidized soon after crystallization, and that the enhanced oxidation state of the system is due to discharge of the second magma pulse near or even on the sea floor. This notion is confirmed by isotope data obtained from the secondary sulfides, which formed shortly after the oxidation of the primary sulfides. The sulfur in the secondary sulfides derived from the oxidized primary sulfides, which mixed with sulfur derived from sea-water sulfate. The dominant influences must have been the isotopically heavy sea-water sulfate and its share in the fluid from which the secondary sulfides deposited.

Another possibility is that the secondary sulfides in the upper layer obtained their isotopically heavy sulfur from the sulfate minerals in the sediments intruded by the second magma pulse. Thermal waters accompanied by magmatic activity dissolved the sulfate minerals. The nearly quantitative reduction of these aqueous sulfate species during serpentinization of the peridotitic rock would cause precipitation of sulfides with comparatively high $\delta^{34} \mathrm{~S}$ values.

\section{L a u kunkangas}

The sulfide-bearing peridotite-gabbro body at Laukunkangas contains $\mathrm{Ni}-\mathrm{Cu}$ sulfides in an intrusive rock series, mainly in norite (Grundström, 1979). The richest occurrence of sulfides is, however, in peridotite close to the basal contact of the body. The graphite schist inclusions in the mafic igneous rocks also contain Ni-Cu sulfides. According to Grundström (1979), the $\delta^{34} \mathrm{~S}$ values in norite are between -4.3 and +3.1 per mil, the average being -0.2 per mil. The graphite-schist inclusions have somewhat lighter sulfur, the $\delta^{34} \mathrm{~S}$ values ranging from 0.5 to -6.5 per mil, with -2.6 as an average.

Grundström (1979) states that the graphite schist inclusions obtained some nickel from the enclosing norite, and hence the nickelcontent in the inclusions is up to 2.5 per cent in the sulfide phase. The corresponding value in norite is between 3.5 and 6 ; in the graphite-schist wall rock outside the mafic body the nickel content is only ca. 0.4 per cent in sulfide phase. The chemical composition of the sulfides in black schist inclusions shows that they are of mixed origin. Hence their sulfur isotope composition is also an admixture of isotopically light black schist sulfides and magmatic sulfides of about zero $\delta^{34} \mathrm{~S}$ value. 
Oravain en

According to Isohanni (1979), the ultramafic body at Oravainen is located in a high metamorphic mica-gneiss environment off the coast in the Bothnian Bay. The body is a subvertical pipe with a horizontal section of ca. $75 \times 30 \mathrm{~m}$ extending more than $240 \mathrm{~m}$ in depth. The margin of the body against the gneissic wall rock is fine-grained gabbro that grades inwards into metaperidotite and finally into a metadunitic core. The massive ores are located in metadunite and the disseminated ores in the marginal zones. The sulfide mineral assemblage consists mainly of pyrrhotite, pentlandite and chalcopyrite.

The sulfur isotope composition was analysed from 12 samples, 2 of which were from sulfide-bearing graphite schist in wall rock and 10 from Ni-Cu ore. The results are shown in Table 1. The isotopic composition of the sulfides in the ore is very homogeneous, the $\delta^{34} \mathrm{~S}$ values ranging from +2.4 to +3.4 , with an arithmetic mean of +2.8 per mil. The two determinations on graphitic mica gneiss yielded -8.1 and -7.8 per mil clearly indicating a different origin for the sulfides.

\section{Discussion}

The sulfur isotope compositions analysed and cited above for $\mathrm{Ni}-\mathrm{Cu}$ occurrences in southern and central Finland deviated little from the meteoritic value and from the value for magmatic, mantle-originated sulfides. If the values analysed are weighted by the sulfide content of the ores, the distribution of sulfur isotope ratios is rather homogeneous. The deviating values shown by the analyses above are mainly due to extreme ore types the percentage of which, however, is neglible compared with the whole sulfide mass. The values given above suggest that the initial sulfur isotope composition was ho- mogeneous in all the ultramafic bodies being ca. +2.5 at Hitura, +2.0 at Kotalahti, close to zero at Kylmäkoski, ca. - 1 at Vammala, +2.8 at Oravainen and close to zero per mil at Laukunkangas. At Vammala the sulfides in the upper ultramafic layer deviate significantly from those in the $\mathrm{Ni}-\mathrm{Cu}$ ore proper in isotope composition. The weak, iron-rich sulfide dissemination in the upper layer is presumably of different postmagmatic origin than the magmatic Ni-Cu sulfides in the lower ultramafic layer. At Hitura and Oravainen the isotopic composition of the sulfides in the ultramafic body deviates significantly from that of the sulfides in the wall-rock gneiss. The same is true for the sulfides in the Laukunkangas mafic body and the graphite-schist inclusions, and for the Kylmäkoski ultramafic body and the graphitic ore type. It is unlikely that a considerable or major part of the sulfides in the ores studied originated from the wall rock by assimilation; they are more probably of magmatic origin.

The wall-rock sulfides and the nickel-rich sulfides in ultramafic rocks were admixed across the contacts between the rock types. The admixing is well documented in the environment of the Hitura ore body, where a weak $\mathrm{Ni}-\mathrm{Cu}$ dispersion halo exists in wall-rock gneisses. Likewise, the black schist inclusions in Laukunkangas owe their Ni-Content to admixing with magmatic sulfides.

All the deposits studied have undergone metamorphic recrystallization and redistribution of sulfides. It is therefore hard to decide whether the formation of the nickel dispersion halo around the Hitura ore body and the admixing of magmatic and sedimentary sulfides in inclusions are primary magmatic features or whether they were formed by mobilization of sulfides during metamorphism.

The Jussi ore body at Kotalahti may have been formed by long-distance mobilization of magmatic sulfides. The slight depletion in ${ }^{34} \mathrm{~S}$ 
that characterizes the Jussi ore body does not occur in the main intrusive of Kotalahti. The $\delta^{34} \mathrm{~S}$ values in the small ore body of Kylmäkoski are more variable than those in the Kotalahti body. The complex metamorphic history and the effect of wall rock sulfide contamination easily leave their imprint on the sulfides of a small ultramafic body.

The sulfur isotope composition of the $\mathrm{Ni}-\mathrm{Cu}$ occurrences in southern and central Finland indicates that most of the sulfides studied are of magmatic origin. The original isotope composition varies between $\delta^{34} \mathrm{~S}$ values +2.8 and -1 per mil, but it is too early to conclude whether the differences are significant in terms of the intrusion type or environment

\section{References:}

Ault, W. U. and Kulp, J. L. (1959) Isotopic geochemistry of sulphur. Geochim. Cosmochim. Acta 16, 201-235.

Boyd, R. and Mathiesen, C. O. (1979) The nickel mineralization of the Råna mafic intrusion, Nordland, Norway. Can. Mineralogist 17, 287298.

Chamberlain, J. A. (1967) Sulfides in the Muskox intrusion. Can. J. Earth Sci. 4, 105-153.

Gaál, G. (1972) Tectonic control of some $\mathrm{Ni}-\mathrm{Cu}$ deposits in Finland. Int. Geol. Congr. 24th. 4, $215-224$.

Godlevskii, M. N. and Grinenko, L. N. (1963) Some data on the isotopic composition of sulfur in the sulfides of the Norilsk deposit. Geochemistry No $1,35-41$.

Groves, D. I., Barrett, F. M. and McQueen, K. G. (1979) The relative roles of magnetic segregation, volcanic exhalation and regional metamorphism in the generation of volcanic-associated nickel ores of Western Australia. Can. Mineralogist 17, 319-336.

Grundström, L. (1979) Laukunkankaan Ni-Cu esiintymä Kaakkois-Suomessa. Unpubl. licentiate thesis, Univ. Turku, $57 \mathrm{p}$.

Haapala, P. S. (1969) Fennoscandian nickel deposits. In Magmatic ore deposits, ed. H. D. B. Wilson. Econ. Geol. Monograph 4, 262-275. of the deposit. Late magmatic or metamorphic processes have caused local variation in isotope composition, and the study shows that detailed and comprehensive data on sulfur isotopes would shed new light on the metamorphic history and origin of the $\mathrm{Ni}-\mathrm{Cu}$ occurrences.

Acknowledgements - The authors are indebted to Rautaruukki Oy and Outokumpu Oy for permission to publish the Oravainen sulfur isotope data; to Mr. M. Isohanni, lic. phil. for the material on the Oravainen deposit which he put at the author's disposal; to Mrs. Marja Koistinen for drawing the figures; to Mrs. Gillian Häkli, B.A., for correcting the English of the manuscript and to the Finnish National IGCP Committee of the Academy of Finland for financing the study.

Häkli, T. A. (1963) Distribution of nickel between the silicate and sulphide phases in some basic intrusions in Finland. Comm. geol. Finlande Bull. 209, 59 pp.

- (1971) Silicate nickel and its applications to the exploration of nickel ores. Geol. Soc. Finland Bull. 43, 247-263.

- , Hänninen, E., Vuorelainen, Y. and Papunen, H. (1976) Platinum-group minerals in the Hitura nickel deposit, Finland. Econ. Geology 71, $1206-1213$.

- , Vormisto, K. and Hänninen, E. (1979) Vammala, a nickel deposit in layered ultramafite, Southwest Finland. Econ. Geology 74, 11661197.

Isohanni, M. (1979) Oravaisten $\mathrm{Ni}-\mathrm{Cu}$ esiintymä; Unpublished report, Outokumpu Oy, Exploration.

Liebenberg, L. (1970) The sulfides in the layered sequence of the Bushweld igneous complex. In Symposium on the Bushweld igneous complex and other layered intrusions (eds. D. J. L. Visser and G. von Gruenewaldt) Geol. Soc. S. Africa, Spec. Publ. 1, 108-207.

Lusk, J. (1976) A possible volcanic-exhalative origin for lenticular nickel sulfide deposits of volcanic association with special reference to those in Western Australia. Can. J. Earth Sci. 13, 451-458.

Mainwaring, P. R. and Naldrett, A. J. (1977) Coun- 
try-rock assimilation and the genesis of $\mathrm{Cu}-\mathrm{Ni}$ sulfides in the Water Hen intrusion, Duluth complex, Minnesota. Econ. Geology 72, 12691284.

Mäkelä, M. and Tammenmaa, J. (1977) A system for precise sulfur isotope analysis by a small mass spectrometer. Geol. Survey Finland, Rep. Invest 20, $23 \mathrm{pp}$.

Naldrett, A. J. (1966) The role of sulphurization in the genesis of iron-nickel sulphide deposits of the Porcupine district, Ontario. Can. Inst. Min. Met. Trans. 69, 147-155.

Ohmoto, Hiroshi (1972) Systematics of sulfur and carbon isotopes in hydrothermal ore deposits. Econ. Geology 67, 551-578.

Papunen, H. (1970) Sulphide mineralogy of the Kotalahti and Hitura nickel-copper ores, Finland. Ann. Acad. Sci. Fenn. Ser A III, 109, 82 pp.

- (1974) The sulfide mineral assemblages of some Finnish Ni-Cu deposits. In Problems of Ore Deposition 4th IAGOD Symposium, Varna, vol. 2, $311-319$.

- (1977) Genetic aspects of the sulfide Ni-Cu deposits of Southern Finland. In Correlation of Precambrian (ed. A. V. Sidorenko) Nauka, Moscow, 343-348.
- and Koskinen, J. (1978) Geology of the Kotalahti $\mathrm{Ni}-\mathrm{Cu}$ ore. In Metallogeny of the Baltic Shield, Helsinki Symposium 1978, The Academy of Finland Excursion Guide, 69-82.

- Häkli, T. A. and Idman, H. (1979) Geological, geochemical and mineralogical features of sulfide-bearing ultramafic rocks in Finland. Can. Mineral. 17, 217-232.

Sasaki, Akira (1968) Sulphur isotope study of the Muskox intrusion, district of Mackenzie. Geol. Survey Canada, paper 68-46, 68 p.

Seccombe, P. K., Groves, D. I., Binns, R. A. and Smith, J. (1977) A sulphur isotope study to test a genetic model for $\mathrm{Fe}-\mathrm{Ni}$ sulfide mineralization at Mt. Windarra, Western Australia. In Stable isotope Developments in the earth sciences (ed. B. W. Robinson) N.Z. Dep. Sci. Ind. Res. Bull. 220, 187-202.

Stanton, R. L. (1972) Ore Petrology. McGraw-Hill, New York.

Tontti, M., Koistinen, E. ja Lehtonen, M. K. A. (1979) Kotalahden nikkelivyöhykkeen monimuuttuja-analyysi. Abstract: A multivariate analysis of the Kotalahti Nickel Belt. Geol. Survey Finland, Rep. Invest. 36, 34 pp.

Manuscript received, February 15, 1980 